\title{
nature
}

\section{Combating the exploiters of creationism}

Creationism's resurgence and its exploitation by politicians pose challenges to scientists that cannot be ignored. More resolute activism is required if a decent scientific education is not to be denied to some young Americans.

K ansas state geologist Lee Allison gave American Geophysical Union (AGU) members a strong dose of reality last week about the resurgent creationist movement's success in eliminating evolution and aspects of the Earth sciences from the school curriculum in his home state, and how the political right in the United States is capitalizing on that Christian fundamentalist agenda (see page 847).

Scientists are easy targets, says Allison; they aren't organized to lead political battles, they aren't media savvy and they are easily pigeon-holed as members of a liberal élite. They are even easier targets for extremists than gays, he maintains, providing a telling political analysis of last summer's creationist victory in Kansas. The conservative wing of the Republican Party in Kansas that led the creationist drive originally planned to use gay rights as the central focus of its campaign, but that target was dropped in favour of scientists. After all, explains Allison, most cities in the United States have an annual 'Gay Pride' day or parade, but when was the last time people saw scientists proudly parading themselves as such in the streets?

Science Days, or even Science Pride Days, would not provide an adequate response to creationism or its political exploitation, but that scale of grass-roots organizing is what is required to bring rationality and intelligence to discussions over local school science curricula. New Mexico recently provided a blueprint of how scientists can succeed in the political trenches of America's neighbourhoods. Scientists organized, they walked precincts and, in October, got candidates elected to the state school board, which returned the teaching of scientific fundamentals to the state's school curriculum.

But such efforts - described as the new "cold war" by some scientists - are not necessarily easy. At a session on evolution at last week's AGU meeting in San Francisco, a scientist asked: "How do you fight creationists if you are a liberal atheist from New York?". That question highlights the divide between some members of the scientific community and mainstream America today. Certain scientific discoveries, alarming to some of the public, are being manipulated by political forces - in particular, AGU panellists noted, the "Christian right" and conservative Republicans — so as to make science seem a threat to individual religious views in America.

Most scientists tend to avoid public confrontation. But the key to the battle for the teaching of good science in the presence of fundamentalism is to be more resolute in informing the public of the important role of science and actively to oppose the use of distorted perceptions of science as a political vehicle to create what one panellist last week called "the dark age" of Kansas. To that end, scientists need to reach out, to become involved in local school-board issues and to seek election to ensure appropriate scientific curricula.

Scientists new to the political trenches should not get locked into debates about creationist beliefs, which at the least can shift the focus to a form of intellectual sport and at worst collapse into fruitless opposed assertions or even pitched battles. Experience suggests that scientists should instead focus on the fundamental question: "Do people want good science taught in schools?", clearly and justifiably linking today's understanding of the Earth's history and of evolution inextricably with the science that will allow parents' offspring to be able to grow up and solve the problems of disease, to eat healthier foods that will prolong and improve their lives, and to reap the lifestyle advantages that technology brings.

As scientists rally in Kansas next year, hopefully to defeat the pro-creationist forces on the state school board, the plains state will be a political test for a new resolve among the US scientific community. But given the political forces riding the fundamentalist wave, it will take coordination, coherence and some powerful advocacy drawn from the ranks of many independently minded scientists to carry the day.

\section{An ill-judged cut}

\section{A large reduction in German support for agricultural research in the developing world sets a bad example.}

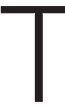
he turn of the year is a time for good resolutions, the arrival of the year 2000 even more so. Symbolically, therefore, Germany's decision to slash funds for the international system of agricultural research (see page 845) could not have come at a worse moment. What is much worse, it hits an agency that deserves every support. The Consultative Group for International Agricultural Research (CGIAR), established in 1971, has contributed substantially to many significant advances in agriculture that are likely to have saved the lives of millions.

But its work is far from finished. According to recent estimates, global food production will have to double within the next 30 years in order to meet the constantly rising demand. As agriculture in developing countries cannot be separated from environmental factors, some of the organization's 16 institutes worldwide have in recent years carefully shifted their priorities towards research in the management of natural resources - a well-advised policy considering the rapidly growing number of people affected by water shortages. It should go without saying that these socially explosive challenges deserve major efforts in basic research and technology. The CGIAR's responsible development of partnership with the private sector further strengthens the case for its funding.

The international system of agricultural research will not collapse because of Germany's move — provided it is not imitated by others. Those targeting agricultural research in the developing world for cuts should bear in mind that such support is not only a question of morals and conscience. It is also an investment towards global peace. 